\title{
Kualitas Telur Puyuh yang Beredar di Pasar Tradisional di Kecamatan Kaliwates Kabupaten Jember
}

\section{The Quality of Quail Eggs Circulating in Traditional Markets in Kaliwates District, Jember Regency}

\author{
Reikha Rahmasari $^{* 1}$, Rosa Tri Hertamawati, Danu Wahyu Cahyono \\ *Program Studi Manajemen Bisnis Unggas, Jurusan Peternakan Politeknik Negeri Jember, \\ Jl. Mastrip POX 164, Jember \\ ${ }^{1} \mathrm{E}$-mail: reikha.rahma19@polije.ac.id
}

\begin{abstract}
The purpose of this research was to analyz the quality of quail eggs circulating in the traditional market in Kaliwates district of Jember Regency. This study used experimental method with Complete Randomized Design (CRD) with five treatments and each treatment have three replications. Treatments in this study were market location: P1(Kepatihan market), P2 (Tanjung market), P3(Market Mangli), P4 (Tegal Besar market) and P5 (Pelita market). The observed parameters consist of egg weight, egg white index, egg yolk index and quail egg unit haugh. The data were analyzed by Analysis of Variance (ANOVA). The results showed that the quality of quail eggs circulating in Kaliwates district of Jember regency have same quality (no significant difference $(\mathbf{P}>0.05)$ ) between the five traditional markets on this study and have good quality according to standard.
\end{abstract}

Keywords: quail egg quality, egg yolk index, egg white index, haugh unit

\section{Pendahuluan}

Telur sebagai produk peternakan yang memberikan sumbangan besar bagi tercapainya kecukupan gizi masyarakat. Total produksi telur di kabupaten Jember pada tahun 2016 sebanyak 13.827.686 butir telur ayam ras, telur itik (bebek) dan telur puyuh, untuk telur puyuh sebanyak 81.955 [1].

Telur puyuh merupakan sumber protein hewani yang potensial dilihat dari nilai nutrisi yang dimilikinya. Menurut [2] setiap $100 \mathrm{~g}$ telur puyuh mengandung $15 \mathrm{~g}$ protein dan $10,20 \mathrm{~g}$ lemak. Nilai nutrisi tersebut tidak terlalu berbeda degan telur ayam dan itik, dengan kandungan protein dan lemaknya berturut-turut adalah 12,8 $\mathrm{g}$ dan $11,5 \mathrm{~g}$ untuk telur ayam, $13,1 \mathrm{~g}$ dan $14,3 \mathrm{~g}$ untuk telur itik.

Telur puyuh memiliki sifat yang mudah rusak. Kerusakan yang sering terjadi berupa kerusakan fisik, kimia dan kerusakan yang diakibatkan oleh mikroorganisme, baik secara langsung atau tidak langsung. Cemaran mikroorganisme tersebut dapat berasal dari tanah, udara, air, debu dan kotoran puyuh. Beberapa faktor yang dapat mempengaruhi penyimpanan telur yaitu temperatur, penyimpanan, dan bau yang berada di sekitar penyimpanan telur. Telur akan mengalami perubahan kualitas seiring dengan lamanya penyimpanan, semakin lama waktu penyimpanan akan mengakibatkan terjadinya banyak penguapan cairan di dalam telur dan menyebabkan kantong udara semakin besar [3]

Umar [4] , menyatakan adanya variasi karakteristik dan kualitas telur antara di peternak dan di pasar. Kualitas telur ayam ras yang beredar di setiap pasar memiliki kualitas yang berbeda-beda karena dipengaruhi oleh suhu, kondisi pasar dan lama penyimpanan [5]. Telur puyuh yang disimpan dari 0 sampai 8 minggu menunjukkan adanya penurunan nilai HU dari 73,72 menjadi 56,93 [6]

Jarak atau pendistribusian telur puyuh yang berbeda-beda setiap pasar juga dapat mempengaruhi umur telur pada konsumen yang pada akhirnya mempengaruhi kualitas telur konsumsi. Kondisi tersebut dikarenakan telur yang dikeluarkan dari 
kloaka segera mengalami perubahan kandungan internal dan strukturnya. Perubahan-perubahan ini terjadi secara irreversible dan terus menerus sekalipun telur di simpan dalam keadaan dan kendali yang baik. Menurut [7] melaporkan bahwa jarak dan pendistribusian telur itik selama 7 dan 14 hari tidak menurunkan kualitas eksternal telur itik yang meliputi berat telur dan indeks bentuk telur namun pendistribusian telur itik selama 7 dan 14 hari telur itik menurunkan kualitas internal telur itik yang meliputi nilai indeks putih, nilai indeks kuning dan nilai haugh unit telur.

Berdasarkan pemaparan di atas menunjukkan jarak atau pendistribusian telur dapat menurunkan kualitas internal telur, oleh karena itu perlu dilakukan penelitian tentang kualitas telur yang beredar di kecamatan Kaliwates kabupaten Jember yang bertujuan untuk mengetahui kualitas telur puyuh yang beredar di pasar tradisional kecamatan Kaliwates kabupaten Jember

\section{MATERI DAN Metode}

Penelitian ini merupakan penelitian eksperimental dengan percobaan Rancangan Acak Lengkap (RAL), menggunakan 5 perlakuan yang masing-masing perlakuan terdiri dari 3 ulangan. Perlakuan dalam penelitian ini berupa (lokasi pasar penjual telur) lokasi pasar yang berada di kecamatan Kaliwates kabupaten Jember.

$$
\begin{aligned}
& \text { P1 }=\text { Pasar tradisional Kepatihan } \\
& \text { P2 }=\text { Pasar tradisional Tanjung } \\
& \text { P3 }=\text { Pasar tradisional Mangli } \\
& \text { P4 }=\text { Pasar tradisional Tegal Besar } \\
& \text { P5 }=\text { Pasar tradisional Pelita }
\end{aligned}
$$

\section{A. Pengambilan Sampel}

Penentuan sampel dalam penelitian ini menggunakan teknik pengambilan sampel purposive sampling yaitu cara pengambilan dengan menetapkan ciri-ciri yang sesuai dengan tujuan. Menurut [8] Arikunto (2006), jika populasi lebih besar atau sama dengan 100 maka sampel diambil 10-25\%, sedangkan jika populasi kurang dari 100 semua harus dijadikan sampel. Sampel ditentukan menggunakan teknik purposive sampling dengan kriteria: pasar tradisional yang memiliki pedagang telur puyuh, ramai pengunjung, dan pasar yang akan dijadikan sampel terletak di kecamatan Kaliwates. Kriteria pedagang: pedagang mampu menjual minimal $1 \mathrm{~kg}$ telur puyuh 1 hari, pedagang memiliki pemasok telur tetap, dan pedagang sebagai pedagang tetap.

Pemilihan pedagang dilakukan secara purposive sampling, sehingga diperoleh jumlah pedagang dari pasar Kepatihan (3 pedagang), pasar Tanjung (4 pedagang), pasar Mangli (2 pedagang), pasar Pelita (3 pedagang), dan pasar Tagal Besar (3 pedagang), masing-masing pedagang diambil sampel telur $3 \mathrm{kali}$ (waktu pengambilan telur) setiap ulangan pedagang diambil 250 gram/20-25 butir telur. Jarak pengambilan telur dari setiap pedagang adalah satu minggu untuk satu pasar.

Setelah diketahui banyak sampel dari masingmasing pasar yang digunakan untuk pengujian kualitas telur, selanjutnya dilakukan teknik pengambilan sampel secara (random sampling) secara proporsional, masing- masing diambil sampel 5 butir telur dari setiap pedagang. Total keseluruhan telur yang digunakan adalah 225 butir telur dari 15 pedagang.

\section{B. Peubah yang diamati}

1) Berat Telur; Berat telur diperoleh dengan menimbang masing-masing telur sampel menggunakan timbangan digital dengan ketelitian dua angka di belakang koma.

2) Indeks Putih Telur; Telur dipecahkan di atas kaca datar, kemudian dengan jangka sorong tinggi dan lebar putih telur diukur. Hasil pengamatan dicatat dan indeks putih telur dapat dihitung menggunakan rumus:

$$
\mathrm{IPT}=\frac{\mathrm{T}}{1 / 2 \times(\mathrm{L} 1+\mathrm{L} 2)}
$$

Keterangan:

$\mathrm{T}$ : tinggi putih telur

L1 : lebar putih telur

L2 : panjang putih telur

3) Indeks Kuning Telur; Pecahkan telur di atas kaca datar, kemudian pisahkan putih telur dengan hati-hati. Ukur diameter dan tinggi kuning telur menggunakan jangka sorong, catat hasil pengamatan. Indeks kuning telur dihitung menggunakan rumus:

$$
\text { IKT }=\underline{\text { Tinggi kuning telur }(\mathrm{mm})}
$$

Diameter kuning telur (mm)

4) Haugh Unit; Pecahkan telur di atas kaca datar dan ukur tinggi putih telur kental menggunakan jangka sorong. Nilai haugh unit dapat dihitung menggunakan rumus: $100 \log \left[(\mathrm{H}+7.57)-\left(1.7^{(\mathrm{W}} \times\right.\right.$ $\left.{ }^{0.37)}\right)$ ], H: tinggi putih telur, W: berat telur.

\section{Hasil Dan Pembahasan}

\section{A. Berat Telur}

Rata-rata berat telur yang beredar di pasar tradisional kecamatan Kaliwates dapat dilihat pada Tabel 1. 
Reikha Rahmasari, Rosa Tri Hertamawati, Danu Wahyu Cahyono. Kualitas Telur Puyuh yang Beredar di Pasar Tradisional di Kecamatan Kaliwates Kabupaten Jember

TABel 1. Berat Telur Puyuh (G)

\begin{tabular}{lcccc}
\hline \multirow{2}{*}{ Pasar } & \multicolumn{4}{c}{ Minggu } \\
\cline { 2 - 4 } & M1 & M2 & M3 & \\
\hline Kepatihan & 12,22 & 11,93 & 11,98 & 12,04 \\
Tanjung & 12,39 & 11,89 & 11,94 & 12,07 \\
Mangli & 11,93 & 11,97 & 12,02 & 11,98 \\
Tegal Besar & 11,63 & 12,02 & 12,04 & 11,90 \\
Pelita & 12,27 & 12,16 & 12,16 & 12,20 \\
\hline
\end{tabular}

Hasil analisis menunjukkan bahwa perbedaan lokasi pasar terhadap berat telur puyuh yang beredar di pasar tradisional kecamatan Kaliwates kabupaten Jember menunjukkan hasil tidak berbeda nyata $(\mathrm{P}>0,05)$.

Rata-rata berat telur yang beredar dari lima lokasi pasar tradisional berkisar antara 11,90-12,20 g. Rataan berat telur tertinggi diperoleh dari pasar Pelita dengan berat $12,20 \mathrm{~g}$ dan rata-rata berat terkecil dari pasar Tegal Besar 11,90 g. Rata-rata berat telur yang dijual di pasar Mangli dan pasar Tegal Besar termasuk dalam klarifikasi telur besar, sedangkan untuk telur puyuh yang dijual di pasar Tanjung, pasar Kepatihan, pasar Pelita, termasuk dalam kualifikasi sangat besar. [9] bahwa telur puyuh memiliki berat sekitar 8\% dari berat badan induk atau sekitar 10-11 g.

Perbedaan nilai rata-rata berat telur puyuh disebabkan oleh beberapa faktor diantaranya faktor pakan, jenis burung puyuh dan lingkungan, [10] menyatakan bahwa faktor yang dapat mempengaruhi berat telur antara lain yaitu jenis burung puyuh, jenis pakan, jumlah pakan, lingkungan kandang, dan kualitas pakan. Pada penelitian ini, perbedaan lokasi pasar tidak mempengaruhi berat telur puyuh yang di jual, hal ini diduga karena jenis puyuh dan jenis pakan yang digunakan sama atau pedagang mempunyai pasokan telur puyuh dari peternakan yang sama. Faktor lain adalah umur simpan telur puyuh pada kondisi yang sama. Puyuh yang disimpan 0 sampai 3 minggu mempunyai bobot $10,74-11,45 \mathrm{~g}$, nilai tersebut lebih tinggi dari pada telur yang disimpan selama 4 sampai 5 minggu, yaitu 10,25-10,38 g [11].

\section{B. Indeks Putih Telur}

Rata-rata nilai indeks putih telur dari telur yang beredar di pasar tradisional kecamatan Kaliwates dapat dilihat pada Tabel 2.

\begin{tabular}{lllll}
\hline \multirow{2}{*}{ Pasar } & \multicolumn{3}{c}{ Minggu } & Rata-rata \\
\cline { 2 - 4 } & M 1 & M 2 & M 3 & \\
\hline Kepatihan & 0,119 & 0,116 & 0,095 & 0,110 \\
Tanjung & 0,122 & 0,124 & 0,096 & 0,114 \\
Mangli & 0,124 & 0,093 & 0,057 & 0,092 \\
Tegal Besar & 0,112 & 0,077 & 0,081 & 0,090 \\
Pelita & 0,098 & 0,126 & 0,088 & 0,104 \\
\hline
\end{tabular}

Perbedaan lokasi pasar tradisional terhadap indeks putih telur menunjukkan hasil tidak berbeda nyata $(\mathrm{P}>0,05)$. Nilai indeks putih telur puyuh yang beredar di pasar tradisional kecamatan Kaliwates kabupaten Jember tergolong dalam kualitas telur yang segar dengan nilai indeks putih telur berkisar 0,90-0,114.

Rata - rata indeks putih telur tertinggi dimiliki telur yang berasal dari pasar Tanjung, yaitu sebesar 0,114 sedangkan rataan terendah yaitu telur dari pasar Tegal Besar dengan nilai 0,098. Nilai indeks putih telur hasil pengamatan masih berada dalam kisaran kualitas telur baik. [12] Nasution (2017) menyatakan indeks putih telur puyuh yang baik bekisar antara $0,05-0,18$.

Nilai rata-rata indeks putih telur puyuh untuk pasar Kepatihan, Tanjung, Mangli, dan Pelita tergolong dalam mutu II yaitu berkisar 0,092-0,114, sedangkan pasar Tegal Besar tergolong dalam mutu III dengan nilai 0,090. [13] SNI 3926 (2008) yang menyatakan bahwa indeks putih telur mutu I $0,134-$ 0,175, mutu II 0,092-0,133, mutu III 0,50-0,091. Di referensi lainnya, penyimpanan 1-8 minggu menunjukkan adanya penurunan pada indek putih telur puyuh dari 0,113 menjadi 0,067 [6].

Penurunan indeks putih telur puyuh dapat dipengaruhi oleh pertukaran gas antara udara luar dengan isi telur melalui pori-pori kerabang telur dan penguapan air akibat dari lama penyimpanan, suhu, kelembapan dan porositas kerabang telur [14]. Semakin lama masa penyimpanan telur maka kekentalan akan semakin menurun, akibatnya diameter telur akan semakin melebar, dan jika dihitung maka nilai indeks putih telur akan semakin menurun [15].

\section{Indeks Kuning Telur}

Rata-rata nilai Indeks Kuning Telur dari telur yang beredar di pasar tradisional kecamatan Kaliwates dapat dilihat pada Tabel 3. 
TABEL 3. INDEKS KUNING TELUR PUYUH

\begin{tabular}{lcccc}
\hline \multirow{2}{*}{ Pasar } & \multicolumn{3}{c}{ Minggu } & \\
\cline { 2 - 3 } & M1 & M2 & M3 & \\
\hline Kepatihan & 0,408 & 0,385 & 0,366 & 0,387 \\
Tanjung & 0,404 & 0,441 & 0,342 & 0,396 \\
Mangli & 0,417 & 0,378 & 0,247 & 0,347 \\
Tegal & 0,363 & 0,274 & 0,293 & 0,310 \\
Besar & 0,321 & 0,440 & 0,297 & 0,353 \\
Pelita & & & & \\
\hline
\end{tabular}

Hasil analisis menunjukkan bahwa perbedaan lokasi pasar terhadap indeks kuning menunjukkan hasil tidak berbeda nyata $(\mathrm{P}>0,05)$. Indeks kuning telur puyuh yang beredar di pasar tradisional kecamatan Kaliwates kabupaten Jember tergolong dalam kualitas telur yang baik dengan nilai indeks kuning telur berkisar 0,310-0,396. Rata-rata indeks kuning telur tertinggi didapat dari telur yang berasal dari pasar Tanjung sebesar 0,396 sedangkan indeks kuning telur terendah telur dari pasar Tegal Besar sebesar 0,310. Winarno dan Koswara [16] mengemukakan bahwa indeks kuning telur bekisar $0,22-0,45$

Indeks kuning telur burung puyuh untuk pasar Tanjung tergolong pada mutu II dengan nilai indeks kuning telur 0,387 sedangkan untuk pasar Kepatihan, pasar Mangli dan pasar Pelita tergolong pada mutu III dengan nilai indeks kuning telur berkisar 0,347-0,387 untuk pasar Tegal Besar memiliki nilai indeks kuning telur di bawah mutu III dengan dengan nilai indeks kuning telur 0,310. [13] SNI 3926 (2008) menyatakan bahwa nilai indeks kuning telur mutu I 0,458-0,521, mutu II 0,394 - 0,457, mutu III 0,330-0,393. Pytel dan Cwikova (2018) menyatakan bahwa telur puyuh yang disimpan selama 1-8 minggu akan mengalami penurunan indeks kuning telur dari 0,485 menjadi 0,426 .

Penurunan indeks kuning telur dapat diakibatkan oleh lamanya waktu penyimpanan. Novika [17] menyatakan umur telur mempengaruhi nilai indeks kuning telur, semakin lama waktu penyimpanan maka nilai indeks kuning telur semakin kurang yang disebabkan oleh bertambahnya ukuran kunir telur sebagai akibat perpindahan air dari putih telur ke kuning telur. Kekuatan dan elastisitas membran vitelin selama penyimpanan mengalami penurunan yang menyebabkan kuning telur melebar sehingga nilai indeks kuning telurnya menurun [18]. Soeparno [19] menyatakan bahwa tekanan osmotik kuning telur lebih besar dari putih telur sehingga air dari putih telur akan berpindah menuju kuning telur, proses tersebut mengakibatkan penurunan elastisitas membran viteline dan membesarnya diameter kuning telur.

\section{Nilai Haugh Unit}

Rataan nilai Haugh Unit telur yang beredar di pasar tradisional kecamatan Kaliwates dapat dilihat pada Tabel 4.

TABel 4. Nilai HaUgh Unit TELUR PUyUH

\begin{tabular}{lllll}
\hline \multirow{2}{*}{ Pasar } & \multicolumn{3}{c}{ Minggu } & \multirow{2}{*}{ Rata-rata } \\
\cline { 2 - 3 } & M 1 & M 2 & M 3 & \\
\hline Kepatihan & 58,27 & 58,54 & 57,35 & 58,05 \\
Tanjung & 58,19 & 58,98 & 57,43 & 58,20 \\
Mangli & 58,71 & 57,49 & 55,64 & 57,28 \\
Tegal Besar & 58,57 & 56,62 & 56,47 & 57,22 \\
Pelita & 57,35 & 58,36 & 56,88 & 57,53 \\
\hline
\end{tabular}

Hasil analisis menunjukkan bahwa pengaruh lokasi pasar terhadap nilai haugh unit telur yang beredar di pasar tradisional kecamatan Kaliwates kabupaten Jember menunjukkan tidak berbeda nyata $(\mathrm{P}>0,05)$. Nilai haugh unit telur puyuh dari lima pasar tradisional kecamatan Kaliwates kabupaten Jember tergolong dalam kualitas telur puyuh yang segar dengan nilai haugh unit telur puyuh berkisar 57,2258,20. Hasil pengamatan yang dilakukan menunjukkan bahwa berat telur dan nilai indeks putih telur memiliki kualitas dan mutu yang baik. Rataan tertinggi nilai haugh unit diperoleh dari telur puyuh pasar Tanjung, yaitu sebesar 58,20 sedangkan nilai rataan haugh unit terkecil diperoleh dari telur di pasar Tegal Besar 57,22.

Nilai haugh unit telur puyuh yang beredar di pasar tradisional kecamatan Kaliwates tergolong dalam kualitas B yaitu dengan nilai haugh unit berkisar 57,22-58, 20. Telur berkualitas AA memiliki nilai haugh unit $\geq 72$, untuk telur berkualitas A jika nilai haugh unit berkisar antara 60-72, dan telur kelas B jika nilai haugh unit berkisar antara 31-60 [20]. Telur puyuh yang disimpan selama 1-8 minggu mengalami penurunan nilai haugh unit dari 73,72 menjadi 56,96. Semakin besar nilai haugh unit pada telur puyuh semakin bagus kualitasnya, menunjukkan bahwa telur dalam kondisi segar [6]. Besarnya nilai haugh unit dipengaruhi oleh nilai berat telur dan tinggi putih telur. Berat telur dan tinggi putih telur dipengaruhi oleh lama penyimpanan. Lestari [21], menyatakan bahwa jika bobot telur akan menurun akibat penyimpanan, maka ada kecenderungan tinggi putih telur dan nilai HU akan menurun. Lama penyimpanan telur dapat mempengaruhi nilai haugh unit telur puyuh, semakin lama telur disimpan akan semakin turun nilai haugh unit telur. Tinggi putih telur juga dipengaruhi oleh umur ternak dan suhu penyimpanan telur. Telur ayam umur 35 minggu memiliki nilai tinggi putih telur tertinggi $(5,836 \mathrm{~mm})$ dibandingkan telur dari ayam umur 40 minggu $(5,455$ $\mathrm{mm}), 45$ minggu $(5,153 \mathrm{~mm})$ dan 50 minggu $(4,487$ $\mathrm{mm}$ ) dengan suhu penyimpanan $8-25^{\circ} \mathrm{C}$ [22].

\section{KESIMPULAN}


Reikha Rahmasari, Rosa Tri Hertamawati, Danu Wahyu Cahyono. Kualitas Telur Puyuh yang Beredar di Pasar Tradisional di Kecamatan Kaliwates Kabupaten Jember

Hasil penelitian menunjukkan bahwa kualitas telur puyuh yang berasal dari lima pasar tradisional yang berbeda di kecamatan Kaliwates kabupaten Jember memiliki kualitas dan mutu yang sama, dengan kualitas baik yang ditunjukkan dengan kualitas internal telur puyuh yang meliputi berat telur, nilai indeks putih, indeks kuning dan haugh unit telur puyuh masih masuk dalam standar kualitas telur puyuh yang baik.

\section{DAFTAR PUStaka}

[1] BPS Jawa Timur. 2018. "Produksi Telur Menurut Kabupaten/Kota dan Jenis Unggas 2016 (Kg)." https://www.bps.go.id/.

[2] Lukito, G.A,Suwarastuti A, dan Hintono A. 2012. "Pengaruh Berbagai Metode Pengasinan Terhadap Kadar Nacl, Kekenyalan Dan Tingkat Kesukaan Konsumen Pada Telur Puyuh Asin." Animal Agriculture Journal

[3] Fitrah, R, D Sudrajat, dan Anggraeni. 2018. "Pengaruh Temperatur Lama Penyimpanan Telur Puyuh Tetas Terhadap Daya Tetas, Fertilitas, Bobot Susut Telur Dan Bobot Tetas Telur Puyuh." Jurnal Peternakan Nusantara 4(April): 25-32.

[4] Umar, M.M, Sundari,S , dan Fuah A.M. 2010. "Kualitas fisik telur ayam kampung segar di pasar tradisional, swalayan dan peternak di Kotamadya Bogor." Faculty of Animal Science, Bogor Agricultural University , 2016 Med.Pet Vo:

[5] Afiyah, D,N, dan Nurina,R. 2017. "Kualitas Fisik Dan Mikrobiologi Telur Ayam Ras Di Pasar Tradisional Kota Kediri." Seminar Nasional Hasil Penelitian Universitas Kanjuruhan Malang 2017: 156-63.

[6] Pytel, R, dan Cwikova,O. 2018. "Effect Of Different Storage Times On Japanese Quail Egg Quality Characteristics Sylvie." Potravinarstvo Slovak Journal of Food Sciences vol. 12, 2018, no. 1, p. 560565 (August).

[7] Kunaifi, M. A., M. Wirapartha, dan I K. A. Wiyana PS.2019. Pengaruh Penyimpanan Selama 14 Hari Pada Suhu Kamar Terhadap Kualitas Eksternal Dan Internal Telur Itik Di Daerah Jimbaran. e-jurnal FAPET UNUD, pp. 181-188.

[8] Arikunto. 2006. Prosedur Penelitian Suatu Pendekatan Praktek. Jakarta: PT.Rineka Cipta.

[9] Parizadian, B., Y.J. Ahangari, M.S. Shargh, dan Sardarzadeh,A. 2011. Effects of Different Levels of L-Carnitine Supplementation on Egg Quality And Blood Parameters of Laying Japanese Quail. Int. J. Poultry Sci. 10 (8): 621-625.

[10] Santos, T.C.,A.E. Murakami., J.C. Fanhani, dan C.A.L. Oliveira. 2011. Production And Reproduction of Egg and Meat Type Quails Reared in Different Group Sizes. Brazilian J.Poultry Sci. 13 (1): 9-14.

[11] Utami, S. W., Saadah, S., \& Zuhro, F. 2020. Pengaruh Konsentrasi Daun Belimbing Wuluh (Averhoa Bilimbi L.) dan Lama Penyimpanan terhadap Kualitas Fisik Telur Puyuh. Jurnal Ilmiah Inovasi, 20(3). https://doi.org/10.25047/jii.v20i3.2319

[12] Nasution A,S. 2017. Kualitas Telur Pertama Burung Puyuh (Coturnix coturnix javonica) Dengan
PemberianTepung Daun Pepaya (Carica papaya L) Dalam Ransum. Fakultas Peternakan Program Studi Peternakan Universitas Muhammadiyah. Tapanuli

[13] Standar Nasional Indonesia, 3926. 2008. "Telur ayam konsumsi." Badan Standardisasi Nasional: 1-16.

[14] Yuwanta, T. 2010. Pemanfaatan Kerabang Telur. Program Studi Ilmu dan Industri Peternakan. Fakultas Peternakan. Universitas Gajah Mada, Yogyakarta

[15] Kurnia S,D, Praseno,K dan Kasiyati. 2012. Indeks Kuning Telur (Ikt) Dan Haugh Unit (Hu) Telur Puyuh Hasil Pemeliharaan Dengan Pemberian Kombinasi Larutan Mikromineral (Fe, Co, Cu, Zn) Dan Vitamin (A, B1, B12, C) Sebagai Drinking Water. Jurusan Biologi Fakultas Sains dan Matematika. Universitas Diponegoro. Semarang.

[16] Winarno, F.G. dan Koswara,S. 2002. Telur: Komposisi, Penanganan dan Pengolahannya. MBrio Press. Bogor

[17] Novika, Z., Djaelani, M. A. Dan Mardiati, S. M. 2017. Kualitas Telur Itik setelah Perendaman dengan Ekstrak Daun Salam (Syzygium polyantha) dan disimpan pada Suhu $4^{\circ} \mathrm{C}$. Buletin Anatomi dan Fisiologi. Agustus 2017, 2 (2): 120-127.

[18] Tarigan, R. L. Br. dan Agustina, K. K. 2016. Kualitas Telur Asin Bermedia Kulit Manggis (Garcinia mangostanan L) Berdasarkan Indeks Putih Telur, Kuning Telur, dan Haugh Unit. Indonesia Medicus Veterinus. Januari 2016, 5 (1): 30-37.

[19] Soeparno, R. A., Rihastutidan, I. Dan Triatmojo, S. 2011. Dasar Teknologi Hasil Ternak. Gadjah Mada University, Yogyakarta.

[20] Achmad, J, dan Zakir M,I. 2016. "Kualitas Eksterior Dan Interior Telur Komersil Pada Beberapa Peternakan Di Kabupaten Tanah Laut." 4(2002): 112.

[21] Lestari, L, Mardiati S,M, dan Djaelani M,A. 2018. "Kadar Protein, Indeks Putih Telur, dan Nilai Haugh Unit Telur Itik Setelah Perendaman Ekstrak Daun Salam ( Syzygium polyanthum ) dengan Waktu Penyimpanan yang Berbeda pada Suhu $4^{\circ} \mathrm{C}$ The ", ejournal2.undip.ac.id

[22] de Menezes, P. C., de Lima, E. R., de Medeiros J. P., de Oliveira W. N. K. and Evencio-Neto, J. 2012. Egg Quality of Laying Hens in Different Conditions of Storage, Ages, and Housing Densities. Revista Brasileira de Zootecnia, 41 (9): 2064-2069. doi: 10.1590/S1516-35982012000900014 